\title{
Sustainable development in a developing economy: Challenges and prospects
}

\author{
P. C. Okonkwo \\ Chemical Engineering Department, Ahmadu Bello University, Zaria, Kaduna State, Nigeria.
}

Accepted 21 August, 2013

\begin{abstract}
Sustainable development implies development which ensures maximization of human well being for today's generation which does not lead to declines in future well being. Attaining this path requires eliminating those negative externalities that are responsible for natural resource depletion and environmental degradation. All human activities and developmental projects are associated with environmental degradation in one form or the other with the attendant generation of wastes. As a result of these, environmental problems of various types and intensities have emerged to threaten man's wellbeing and the natural environment which serves as his life support system. In the light of the present global drive towards sustainable development and the concern of the Federal Government of Nigeria, fundamental strategies have been presented here to provide sound basis for comprehensive plans towards environmental management in Nigeria which is a fast developing economy. The basic paradigms of the interaction of man and the environment were used as basis for this study. The socioeconomic potentials of effective environmental management were presented. Application of the strategies has the potentials of contributing significantly to the national GDP and will also ensure that development is in harmony with the environment.
\end{abstract}

Key words: Environment, degradation, sustainable, development, paradigms, pollution, recycling.

\section{INTRODUCTION}

The world Commission on Environment and Development, commonly referred to as the Brundtland Commission, defined the concept of sustainable development as 'development that meets the needs of the present without compromising the ability of future generations to meet their own needs, and at same time takes into account the needs of the poor in the developing world'. Sustainable development can be defined in technical terms as a development path along which the maximization of human well being for today's generations does not lead to declines in future well being. Attaining this path requires eliminating those negative externalities that are responsible for natural resource depletion and environmental degradation. It also requires securing those public goods that are essential for econo- mic development to last, such as those provided by well functioning ecosystems, a healthy environment and a cohesive society. Sustainable development also stresses the importance of retaining the flexibility to respond to future shocks, even when their probability, and the size and location of their effects, cannot be assessed with certainty.

The scope and scale of environmental problems has expanded considerably over the past three decades (Colby, 1991). This expansion range from pollution issues at local, regional and then international levels, to deforestation, soil erosion, declining water tables, and other forms of national resource depletion and degradation, to global concerns such as climate change and the ozone layer. This expansion has coincided with 
cedented growth in the scope and scale of human activities, and in many countries, improvements in human welfare. All human activities take place in the context of certain types of relationships between society and biophysical world (the rest of nature). 'Development' involves transformations of these relationships. When human activities took place on a scale that was minor as compared to that of nature's own, it did not matter much whether the relationships were of a 'parasitic' or 'mutualistic' type. However, world population has tripled and the world economy has expanded to 20 times of its size in 1900 (Speth, 1989). Vitousek et al. (1986) have estimated that humankind now is responsible for the consumption of some $40 \%$ of all terrestrial primary productivity. Matter and energy flows- the physical presence of the economy within the ecosphere now rival in magnitude the flow rates of many natural cycles and fluxes.

\section{RECENT SUSTAINABLE DEVELOPMENT ISSUES}

When modeling the impacts of the latest trends in $\mathrm{CO}_{2}$ emissions, projections show that global average temperatures will increase by about $3.5^{\circ} \mathrm{C}$ by 2100 (Climate Action Tracker, 2012). This is well above the $2^{\circ} \mathrm{C}$ of warming considered by many to be threshold for triggering dangerous, runaway climate change (UK Met. Office, 2010). Even with rapid decarbonisation and a green growth revolution, most scientists now consider $2^{\circ} \mathrm{C}$ to be unobtainable, though this remains a target for political negotiations. Such rapid warming has fundamental implications for development and economic activity. More frequent and severe extreme weather, combined with ever growing numbers of people and assets in exposed coastal areas and floodplains will lead to massive economic losses. This is particularly so in Asia, where 125 millon people are expected to be exposed to tropical cyclones by 2030 , double in number in 1990 (IPCC SREX, 2011; Peduzzi et al., 2011). Significant long term shifts and inter-annual variability in agricultural yields will amplify food insecurity through unpredictable supply. In a world of global food supply chains, direct climate impacts will have diverse, distant and indirect effects. For example, based on modeling warming of $4^{\circ} \mathrm{C}$, soya bean yield will be halved, at least in almost every developing country in which it is grown (Osborne et al., 2009).

This threat of dramatic climate change hangs over the world in which resources are already scarce in many regions, with global scarcity of key resources a real risk under business as usual scenarios.

By 2030 , the world will need at least $50 \%$ more food, $45 \%$ more energy and 30\% more water (United Nations Secretary General High Level Panel on Global Sustainability, 2012). Almost one quarter $(23 \%)$ of the substantial increase in crop production achieved over the past four decades was due to the expansion of arable land. Agriculture accounts for about $70 \%$ of water withdrawals, while water extraction from rivers and lakes has doubled since 1960(Turral et al., 2011). Only 13\% of global energy comes at present, from renewable sources, but the imperative of emissions reduction means that renewable energy must increase, with consequences for both land and water resources (Intergovernmental Panel on climate change 2012).

Contemporary globalization presents a paradox of inequality. Inequality between countries (by money metric measures) is declining as a large cohort of developing countries catches with OECD nations in terms of national income and wealth. There is a corresponding change in the balance of global middle class, which Kenny and Summer (2011) expects to grow massively in developing countries in the next 20 years. Taking a metric of an annual level of per capita house-hold consumption of between $\$ 10$ and $\$ 100$ dollars of purchasing power parity (PPP) per day, Kenny and Summer (2011) estimates that the global middle class will increase from 1.8 billion people in 2009 to 4.9 billion by 2030 (United Nations, 2011).

The world environmental conference that took place in Stockholm in 1972 drew world attention to the inextricable links between development and the environment. Incidentally, that conference took place at the height of the draught in the West African Sahel that caused so much human misery and death in that part of the African continent. Since 1972, the twin issues of economic development and environmental protection have engaged the attention of scientists and non scientists alike all over the world (Okonkwo, 2000).

Environmental problems are manifestation of disharmony between human activities and the environment. When human population was small and his technological ability limited his activities inflicted little damage on the environment and such damages were repaired by the regenerative powers of nature.

Although, as population increased and as man's technological capabilities increased, man was able to temporarily dominate nature but at an increasing cost to his well-being and survival. Environmental problems of various types and intensities have emerged to threaten his well-being, and the natural environment which serves as his life-support system. Man has thus realized that development cannot be sustained and managed. There are essentially ecological limits to economic growth. Sustainable development and environmental protection and management are now the major issues facing mankind.

The problem of sustainable development also brought the world together in a convention tagged United Nations Conference on Environment and Development (UNCED of Earth Summit) in Riode Janeiro (Brazil) in 1992. The conference took a critical appraisal of the state of global environment as well as proffered strategies for the mitiga- 


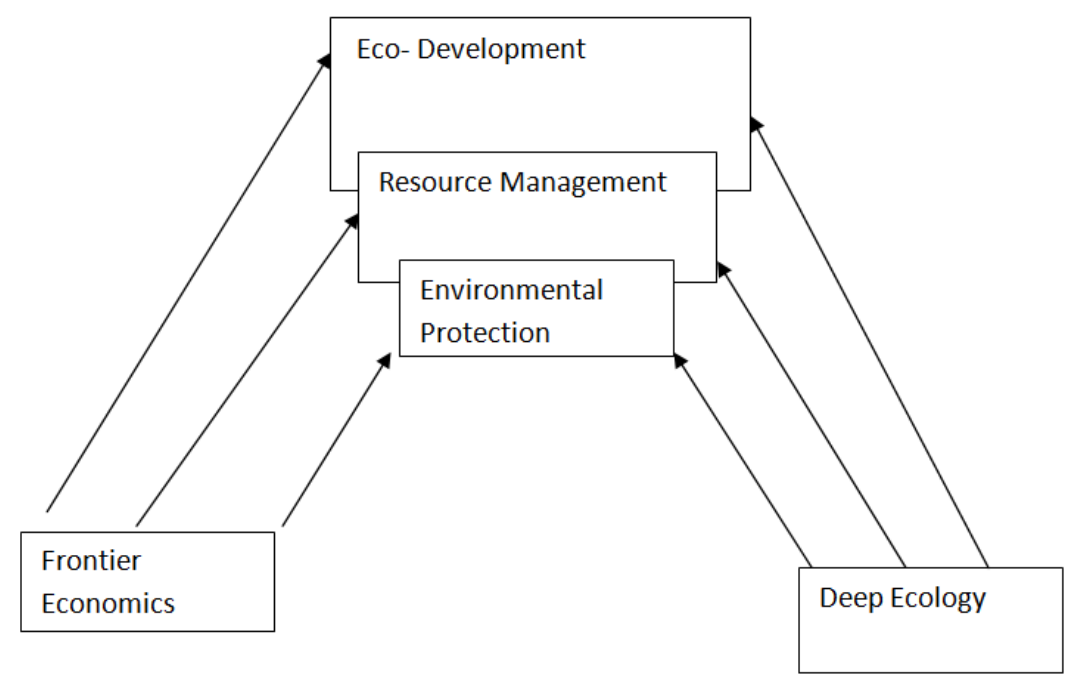

Figure 1. Evolution of environment-development paradigms.

gation of environmental pollution for sustainable development.

To ensure a practicable balance between development and environmental protection conscious efforts must be made as have been highlighted here. These efforts are to be undertaken by all stakeholders (government, community and industries) and should be pursued in a comprehensive manner.

\section{RELATIONSHIP BETWEEN ENVIRONMENTAL MANAGEMENT AND DEVELOPMENT}

There are five basic 'paradigms' of the relationship between humans and nature or of 'environmental management in development' (Colby 1991). Figure 1 shows graphically the nature of the evolutionary relationships between the five paradigms. Each paradigm has different assumptions about human nature, about nature itself and their interactions.

The Frontier Economics treats nature as an infinite supply of physical resources (raw materials, energy, water, soil, air) to be used for human benefit, and as an infinite sink for the by-products of the consumption of these benefits, in the form of various types of pollution and ecological degradation. Deep ecology (Naess, 1973; Sessions and Devall, 1985) advocate the merging of scientific aspects of systems ecology with a 'biocentric' (non-anthropocentric) or harmonious view of the relationship between man and nature. Among the basic tenets are intrinsic' biospecies equality, major reductions in human population, bioregional autonomy, promotion of biological and cultural diversity, decentralized planning utilizing multiple value systems, non growth oriented economies, non dominant (simple or low) technology and more use of indigenous management and technological systems. Environmental protection emphasized rational means for assessing the costs and benefits of development activities. This led to the institutionalization of 'environmental impact statements'. Resource management aim at incorporation of all types of capital and resources- biophysical, human, infrastructural and monetary into calculations of natural accounts, productivity, and policies for development and investment planning. Eco-development (Riddell, 1981; Glaeser, 1984) explicitly sets out to restructure the relationship between society and nature into a 'positive sum game' by reorganizing human activities so as to be synergetic with ecosystem processes and services. Ecodevelopment emphasizes biophysical economics model of a thermodynamically open economy embedded within the ecosystem: biophysical resources (energy, materials and ecological processing cycles) flow from the ecosystem into the economy, and degraded (non- useful) energy and other by products (pollution) flow through to the ecosystem as shown in Figure 2.

In addition to the economic justifications for adopting improved environmental governance practice, there are also strategically defensive justifications for doing so. Negligent corporate environmental stewardship cases have raised the ire of environmental interest groups, government regulators and society in general. Accordingly, improved environmental governance practices are viewed as a way to stave off both public protest and regulatory intervention (Reinhardt, 1999). In short, even for critics who view environmental governance as an overall cost of doing business, there is a degree of acceptance that environmental management practices have strategic defensive value (Palmer et al., 1995; Kiernan, 2001). Khanna (2005) framework depicted in Figure 3 summarizes many of the diverse forces that compel firms to adopt improved environmental manage- 


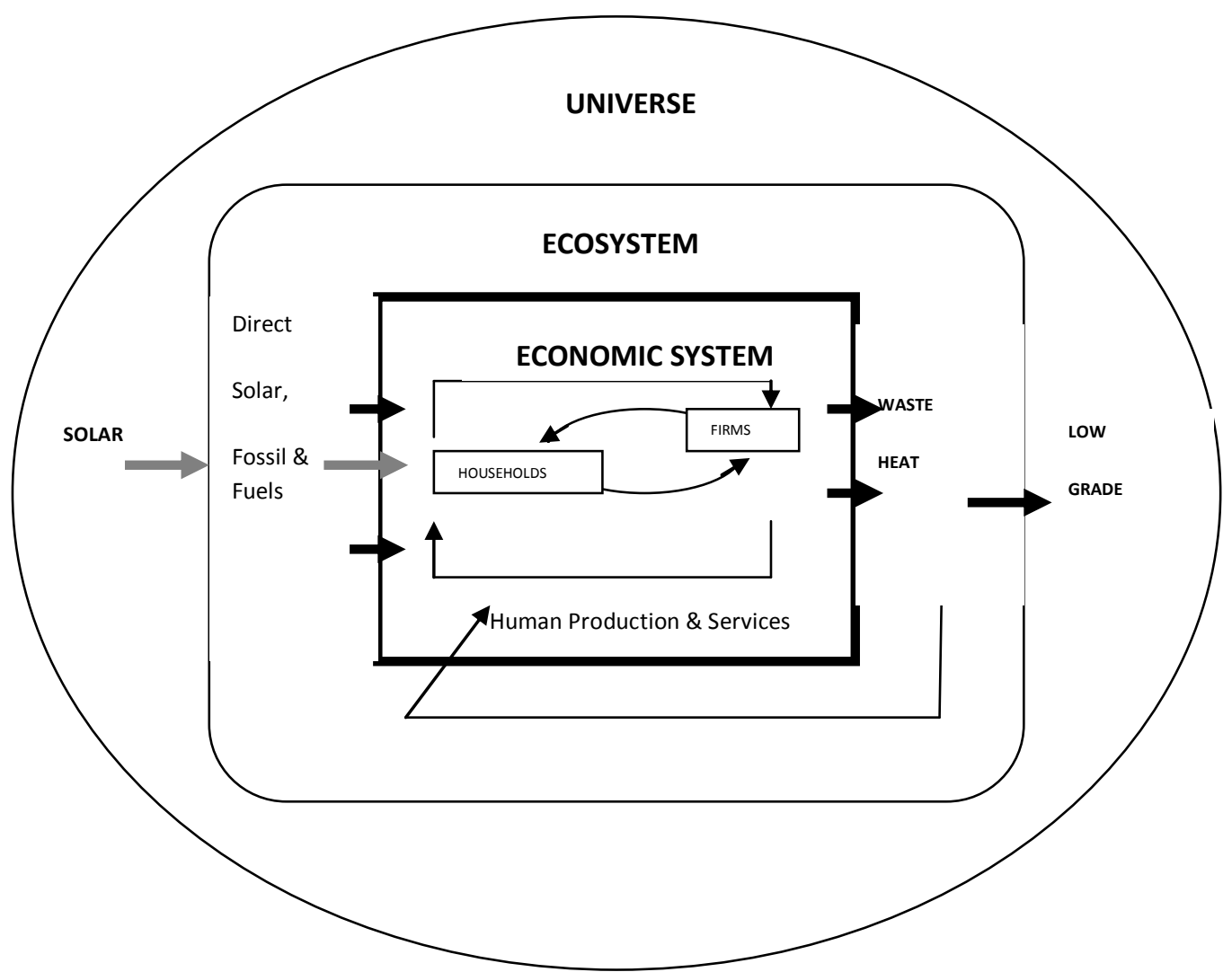

Figure 2. Evolution of environment and development paradigms.

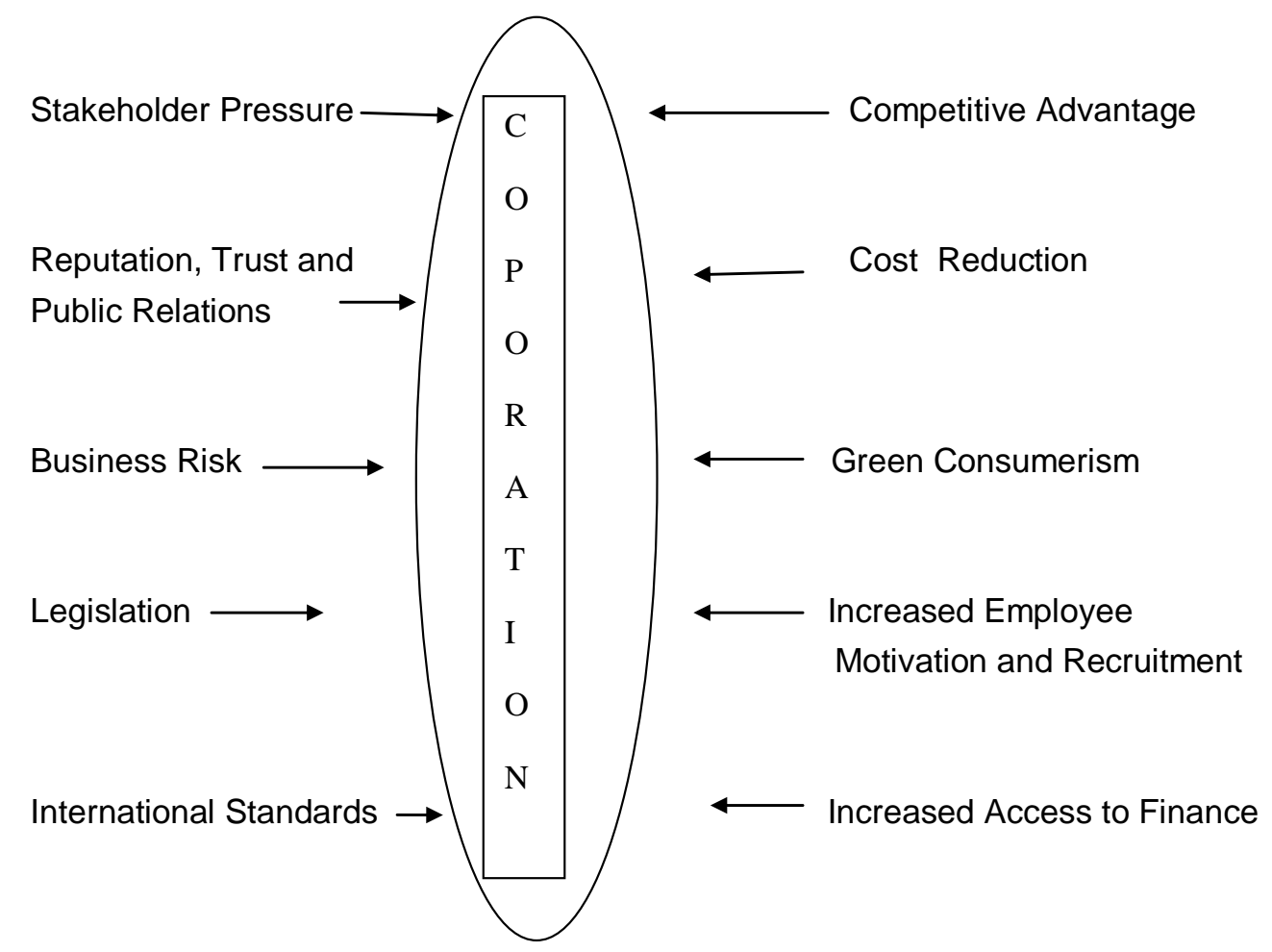

Figure 3. Summary of environmental management catalysts (Khanna, 2005). 
Table 1. Some reported environmental degradation cases.

\begin{tabular}{lll}
\hline Data/place & Case & Impact \\
\hline 1960-Nigeria & $\begin{array}{l}\text { Human Poisoning by gamalin 20 at UCH Ibadan from Cocoa } \\
\text { Production Areas }\end{array}$ & Death of victims \\
& $\begin{array}{l}\text { methyl mercury poisoning of people eating fish polluted by } \\
\text { 1953-1960 }\end{array}$ & Death of 120 victims \\
1967 Ghana & Methyl mercury poisoning from fish & $\begin{array}{l}\text { Death of } 144 \text { victims } \\
1000 \text { deaths }\end{array}$ \\
$\begin{array}{l}\text { 1972 Iraq } \\
\text { Ne88 Onno- }\end{array}$ & $\begin{array}{l}\text { Methyl mercury poisoning from eating of rice } \\
\text { Discharging of water containing high ammonia level into Okinka } \\
\text { river by NAFCON a fertilizer company }\end{array}$ & $\begin{array}{l}\text { Massive killing of fish and aquatic, life and } \\
\text { huge socio-economic problem }\end{array}$ \\
\hline
\end{tabular}

ment techniques. With respect to earlier studies, a great deal is now known about the myriad of ways in which improved environmental governance can benefit firms; yet, the amalgamation of such knowledge into a functional strategic planning framework is still at an evolutionary stage. This has been highlighted previously by Porter and Kramer (2006), who in relation to the broader field of corporate social responsibility (CSR) pointed out that the prevailing approaches to CSR are so fragmented and so disconnected from business and strategy as to obscure many of the greatest opportunities for companies to benefit society.

\section{NATURE OF ENVIRONMENTAL PROBLEMS}

The broad divisions of environment comprises of land (terrestrial), water and air (atmosphere). As a result of man's activities on the environment the natural characteristics and features of these are deterioration of water bodies and devastation of aquatic life, defacing of the land and deforestation, denaturization of the atmosphere,global warming etc. Table 1 shows some reported environmental degradation accidents.

\section{TYPES AND CAUSE OF ENVIRONMENTAL POLLUTION AND DEGRADATION}

There are three main types of environmental pollution namely, air, water and land population. Air pollution is caused by emission of gaseous pollutants into the atmosphere. These pollutants includes: sulphur dioxide, sulphur trioxide, nitrogen dioxide, nitrous oxide, hydrocarbon vapours, photochemical oxidants, particulates, hydrogen sulphide, asbestos dust, herbicides, pesticides, ammonia, carbon monoxide, radioactive substances and combustion products of fossil fuel, etc.

Water pollution is caused by discharge into water bodies the following pollutants: oil and grease, heavy metals, chemical sludges, dyes, acid, bases, hospital wastes, wastes chemicals, etc.
Land pollution is caused by accumulation of machinery scraps, municipal solids wastes (MSW), used packaging materials and plastics, industrial sludges, etc. The source of these environmental pollutants are industries, households, offices and small scale business centers.

\section{Industrial wastes}

Industrialization is the linchpin of development but various disasters which have continuously occurred over the last decades, implicate industries as major contributors to environmental degradation and pollution problems of various magnitudes (Katsina, 2004).

Industrial wastes and emissions contain toxic and hazardous substances most of which can be detrimental to human health. These include heavy metals such as lead, cadmium and mercury, toxic and hazardous substances most of which can be detrimental to human health. These include heavy metals such as lead, cadmium and mercury, toxic organic chemicals like pesticides, polychlorinated bi phenyls (PCB5), petrochemicals and phenolic compounds (FEPA, 1991). In Nigeria, most industries discharge untreated and toxic liquid effluents into open drains, rivers, streams, etc. The solid wastes they generate are often dumped in heaps within the premises, while gaseous emissions and particulates matters are freely discharged into the air (Katsina, 2004). The effect of such uncontrolled pollution as seen in most of the heavily industrialised centers in the country adversely affects the nearby rivers, streams and underground water systems. Table 2 shows some wastes generated in typical manufacturing processes.

\section{Household wastes}

As households (a group of people sharing common cooking and housekeeping arrangements) carryout normal family activities, wastes are generated. Various factors influence the rate and modes of wastes generation, these include population growth, urbanization, industrialization, general economic growth, consumption 
Table 2. Typical waste materials generated from industrial manufacturing.

\begin{tabular}{|c|c|}
\hline Types of industry products & Waste product \\
\hline Metal and metal product & $\begin{array}{l}\text { Cans, ferrous and non ferrous metals rusty scrap iron, metal dust } \\
\text { spent oils, metal dust. }\end{array}$ \\
\hline Wood and wood fibre & Sawn timber, soft board, hard board, particle board. \\
\hline Automotive related industry & $\begin{array}{l}\text { Motor oil, transmission fluid, engine oil, coolant, batteries. } \\
\text { Outdated supplies, paint waste, solvent. }\end{array}$ \\
\hline Paint manufacturing & $\begin{array}{l}\text { Waste rinse waster, solvent spills, paint sludge inks, mixing bath } \\
\text { scrapping, paint soil rags, expired chemicals. }\end{array}$ \\
\hline Paper and paper products & Boxes used cartoons waste paper bags. \\
\hline Plastics & $\begin{array}{l}\text { Soft drink bottles, milk bottles, carriers bags, wrapping, plastic } \\
\text { sachets. }\end{array}$ \\
\hline Photographic laboratories & $\begin{array}{l}\text { Waste chemicals from film development and printing papers, } \\
\text { contaminated water. }\end{array}$ \\
\hline $\begin{array}{l}\text { Cosmetics and detergents (lotion, perfumes, } \\
\text { powders and liquid detergents) }\end{array}$ & Oil and grease, soaps, sludge, waste water. \\
\hline Leather & $\begin{array}{l}\text { Waste chemicals, crushers bagaruwa seeds, trimmings, } \\
\text { flashings, hair skin residues. }\end{array}$ \\
\hline Furniture making & Saw dust, wood pieces \\
\hline Footwear \& leather goods & $\begin{array}{l}\text { Pieces of leather, trimmings, lining, leather dust, adhesives } \\
\text { finishing chemicals }\end{array}$ \\
\hline Oil milling & Sludge and cake \\
\hline Maize and flour production & Bran \\
\hline Chalk production & Sediments \\
\hline Youghurt production & Water and waste water, waste containers. \\
\hline Packaged waster & Plastics \\
\hline Juice production & Plastics \\
\hline Juice production & Plastics, waste water \\
\hline Bread and bakery products & Ash, waste plastic \\
\hline Soap/pomade making & Sludge waste chemicals \\
\hline Polythene making & Plastic wastes \\
\hline Foam making & Waste foam, waste chemicals \\
\hline Tourism (hotels) & $\begin{array}{l}\text { Food scraps and leftovers, wrapping materials (plastic, paper and } \\
\text { packaging, materials) }\end{array}$ \\
\hline
\end{tabular}

patterns and practices of individuals and families (Nwaedozie, 2001). Nigeria Environmental Society in 1991 estimated that $20 \mathrm{~kg}$ of solid wastes is generated per capital income in Nigeria. This $\mathrm{s}$ is equivalent to 3.0 million tonnes in a year given Nigeria's estimated population of 150 million. It is therefore expected that this quantity will continue to grow as the population continue to grow.

Furthermore, using the United Nations estimated figures of $0.54 \mathrm{~kg} /$ day of wastes generation in developing countries, to calculate/estimate the quantity of municipal solid wastes (MSW) generated in Kaduna metropolis and using a population figure of about $1.5 \mathrm{~m}$ people, the waste generated is about 810 tons/day (Hussaini, 2004). The non-biodegradable wastes that are commonly generated in Nigerian household are various forms of plastic wares-bags, wrappers, containers, etc. There are also plastic kitchen and table-wares, e.g buckets, jerry cans, basins, cups, spoons, clothing articles as shoes, etc. the biodegradable wastes constitutes mainly of kitchen wastes. The generation of liquid wastes is essentially minimized by the adoption of water closet system by households however municipal wastes water that run through gutters is equally large in volume hence the need to handle it properly. This waste water has high biooxygen demand content.

\section{Offices and small scale business wastes}

The wastes generated by this category of operators include solid, liquid and gaseous wastes. Waste generators in this category include mechanic workshops, restaurants, small scale manufacturers, filling stations, retail and wholesale shops, government offices, etc.

The typical wastes generated include waste oils and grease machinery scraps, kitchen wastes, plastic containers, scrap papers and office equipment, packaging materials both paper and plastics, hydrocarbon vapours and gases, fuel combusting gases, etc. 


\section{STRATEGIES FOR ENVIRONMENTAL MANAGEMENT}

The current global magnitude and spread of environmental pollution requires a comprehensive approach to the realization of a balance between development and environmental protection to minimize the adverse effects of urbanization, population growth and industrialization which are typical of developing economies on people's lives, the following steps need to be taken on wholesome basis.

The five basic paradigms of man's interaction with nature and his environment provide a sound basis for comprehensive approach to environmental management.

\section{Governmental sectoral policies}

The government needs to develop robust and integrated sustainability goals in sectoral policies. These sectors through the goods and services they provide, contribute to meeting human needs but, through their activities, also impinge on the resources available to other sectors and to future generations. The neglect of this interdependence in sectoral policies may jeopardize other policy objectives and reduce total well being. The following sectors need to be critically integrated.

a) Energy is a key requirement for economic and social development, but certain forms of energy can damage environmental quality when they are produced, transported and used. Energy accounts for $85 \%$ of total greenhouse gas emissions in OECD countries. It also contributes substantially to emissions of sulphur oxides, volatile organic compounds and particulates. The challenge for energy policy is that of reducing the environmental costs of energy production and use while extending access to basic services in developing countries and preserving energy security.

b) Transportation contributes to economic growth and to meeting social needs for access and mobility. But it also contributes to environmental degradation, depletion of non renewable resources, and damage to and loss of human health. The sectoral policy should address:( i) a better integration of transport and land planning policies, (ii) improvements in the use of transport infrastructure, (iii) shifts of demand for new vehicles towards more fuel efficient ones (through fiscal incentives)

c) Past agricultural growth has been achieved with fewer workers and less land, but using more water, chemicals and machinery. This has led to increased pollution and natural resource use, greater homogenization of landscape and destruction of wildlife habitat. The policy direction should address (i) the strengthening of the agricultural knowledge system, to encourage farmers to adopt sustainable methods, (ii) measures to facilitate the structural adjustment of affected workers and communities, (iii) increased use of pollution charges, to correct environmental damage caused by agriculture.

\section{Public education}

The inter-governmental conference on environmental education held in Tblisi (in former USSR) on October 1997 stressed the need for an all - out education programme on environmental problems if nations are to be saved from environmental disasters (Atachia, 1989), it is then necessary to integrate the environmental education into the formal education system, that is, from pre-primary level to tertiary level of education. This will provide the necessary knowledge, understanding, values and skills required by the general public and many occupational groups for their participation in devising solutions to environmental questions. It is also necessary to evolve a vigorous non formal education programme for the "man-in-the street".

\section{Non-governmental organizations (NGOs)}

The National Policy on the environment recognize the need to include NGOs and community based organization (CBOs) in the implementation of its policy objectives (FEPA, 1991). The emerging global rapid, complex and often unpredictable political, institutional, environmental, demographic, social and economic changes has brought to fore the need for alternative solutions to the man's problems and this will essentially revolve around NGOs and CBOs (Achi, 2001).

The establishment of specialized NGOs with thrust towards solving environmental problems should be encouraged. Trust funds should also be established by corporate organization and well meaning individuals from which these NGOs can draw funds for their projects.

\section{Effective town planning}

Government at all levels should embark on development of functional and effective master plans for all centres of development, towns and villages. This will go a long way towards solving many ecological and environmental degradations being experienced. These master plans must also include adequate provision of central waste management schemes for handling of liquid, solid and gaseous effluents from the various human activities. The central waste handling facilities should be part of the plans for housing estates, markets, shopping complexes, industrial areas and designated sections of the towns and cities.

It has been observed that this approach is grossly neglected in the recent developments across the country.

\section{Enforcement of existing environmental Regulations}

Pollution control and waste management objectives can be attained through a variety of policy instruments. These 
instruments can be categorized into:

a. The command-and-control or direct regulation along with monitoring and enforcement.

b. The economic strategies.

The regulatory approach generally requires government to set health or ecology based ambient environmental objectives and specify the standards or amount of pollutants that can be discharged or the technology by which polluters should meet these objectives. In most cases, the command- and-control approach also specifies schedules or approach to the standards, permitting and enforcement procedure for facilities, liability assignment and penalties for non-compliance. The responsibility for defining and enforcing the standards and other requirements is shared in legislatively specified ways between the national, state and local governments.

The major environmental laws in Nigeria could be said to be contained in the following legislations and their subsidiary legislations:

i. Federal Environmental Protection Agency Decree 1992 (AS Amended).

ii. National guidelines and standards for Environmental Pollutions Control in Nigeria (1991).

iii. National Effluent Limitation Regulation section 1.8 of 1991.

iv. Pollution Abatement in industrial and Facilities Generation Wastes S.1.9, 1991.

v. Waste Management Regulations 5.1.15 of 1991.

vi. Environmental Impact Assessment (E.LA) Decree No. 86 of 1992.

vii. Sectional Guidelines on E.I.A.

viii. State Environmental Protection Edicts.

ix. National Environmental Standards Regulations and Enforcement Agency Act 2007 Etc.

These standards however should be continuously updated to meet international standards and accommodate emerging challenges imposed by technological developments, socio-political and cultural changes. Developing economies face challenges of being dumping grounds of the more developed economies and poor implementation of development plans, which lead to inundation of these economies with goods which sometimes are not environmentally friendly, there thus have a robust regulatory framework that will respond adequately to these challenges.

The economic approach on the other hand, incorporating among other things the polluter pay principle (PPP) is usually adopted to introduce more flexible efficiency and cost effectiveness into pollution control measures. Under the PPP, a polluter pays a financial penalty or receives a financial reward for lower levels of pollution, the strict enforcement of the existing regulations and continuous upgrading of these will assure better environmental protections. Furthermore, the polluter pay principle is expected to contribute to the pool of fund for government interventions in environmental and ecological degradation management.

\section{Waste minimization and recycling waste}

Waste minimization is the reduction of waste at source through technological innovation and behavioural change. Waste reduction is considered the top most priority in waste management hierarchy. Recycling involves the basic steps of separating and processing of recyclable waste materials from the waste stream and reselling of the reprocessed items. Recycling materials include glass, paper, cardboard, plastic, metals, etc, recycling is the third preferable option in the waste management hierarchy. The waste management scheme and the potentials for waste recycling activities is shown in Figure 4.

Waste-to-wealth is a product of wastes recycling. In developing economies that face the twin problem of high unemployment and under employment rates, recycling can create a window of opportunities of engaging the population in productive activities of creation of goods and services which can contribute immensely to the GDP of the economy.

Waste minimization an recycling strategy should be practiced at household and industrial sectors to achieve a safe environment.

\section{CONCLUSION}

Environmental management is a complex activity and needs a global and comprehensive approach, to achieve sustainable development. Comprehensive strategies for management of the environment have been presented. Nigeria being a fast developing nation should adopt these strategies to ensure that her developmental efforts are achieved in an environmentally friendly manner.

The need for government action to limit environmental degradation is emphasized however it is expedient that the policy framework need to integrate all the sectors.

The five basic paradigms of relationship between nature and environmental management and development was employed to proffer strategies for comprehensive environmental management in developing nations like Nigeria. The socio-economic potentials of environmental management were highlighted. It has been shown that effective environmental management also provide a window of economic emancipation through engagement in activities of waste-to-wealth; which will result in improved GDP of the nation. It has been suggested that environmental management being dynamic in nature will require continuous review so as to encourage best practices. 


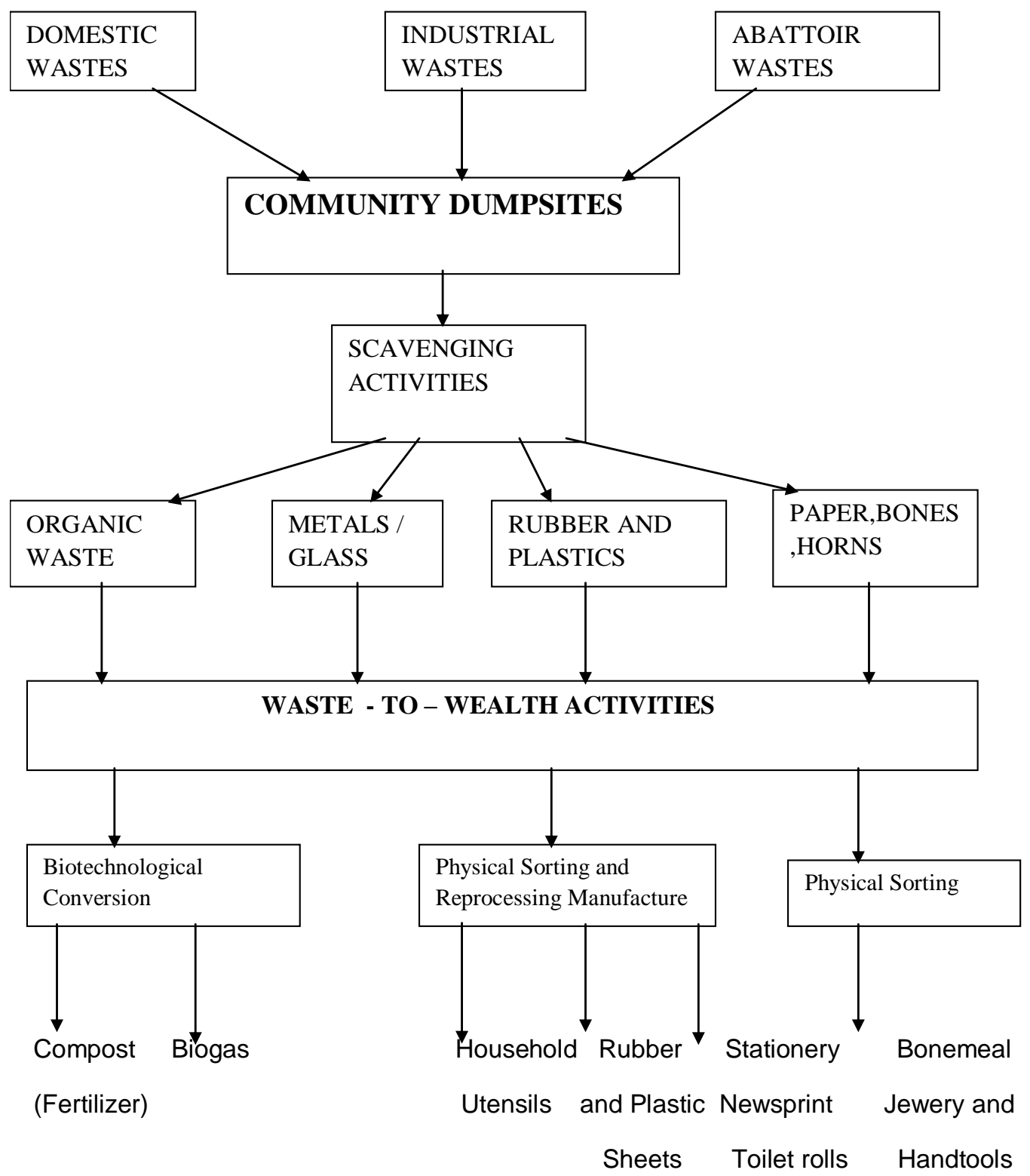

Figure 4. Waste-to-wealth activity and processing profiles.

\section{REFERENCES}

Achi LB (2001). The roles of non-governmental organizations in environmental protection. Nig. J. Ind. Pollut. 1:13-17.

Atachia M (1989) UNEP Environmental Training Policy in the perspective of Development in Formal and Integrated Management of Resources is Africa UNEP-1989.

Climate Action Tracker(2012). http://www.climatectiontracker.org.

Colby ME (1991). Environmental Management in development : the evolution of paradigms, Ecol. Econ. 3:193-213.

FEPA (1991), Guidelines and Standard for Environmental Pollution control in Nigeria. Federal Environmental Protection Agency.

Glaeser B (Editor) (1984). Ecodevelopment: Concepts, Policies, Strategies. Pergamon New York.

Hussaini IG (2004), Technologies and Procedures for sustainable Waste management in Industries, paper presented at workshop on Practical Approach to Waste Management organized by Kaduna Environmental Protection Authority July 4-6 2004.
Intergovernmental Panel on Climate Change (2012). Special Report, Managing the Risks of Extreme Events and Disasters to Advance Climate Change Adaptation.

Katsina MS (2004). Policy issues on Industrial Development and waste Management,paper presented at Workshop on Practical Approach to Waste Management organized by Kaduna Environmental Protection Authority. July 4-6 2004.

Kenny C, Summer A (2011). More money or More Development:What have MDGs achieved? Forthcoming working paper. Washington DC; Center for Global Development

Khanna M (2005). Measuring corporate environmental governance: Adelphi study on ranking corporate environmental governance of companies in Singapore:MSc. Environmental Management Dissertation, Graduate School of Design and Environment. National University Singapore.

Kiernan MJ (2001). Eco- value, sustainability and shareholder value: Driving environmental performance to the bottom line. Environ. Qual. Manage. 10:1-12. 
Naess A (1973) The shallow and deep, long range ecology movements a summary Inquiry 16. pp. 95-100.

Nwaedozie JM (2001). Industrial Waste Water Management Technology in the Tropics. J. Ind. Pollut. 1: 46-53

Okonkwo PC (2000). Unpublished Environmental Audit Report on UNIPETROL PLC Lbricating Oil Blending Plant submitted to Federal Ministry of Environment Nigeria : 2 .

Osborne T, Slingo J, Lawrence D, Wheeler T (2009). Examining the interaction of growing crops with local climate using a coupled clop climate model. J. Clim. 22:6.

Palmer K, Oates WE, Portney PR (1995). Tigthening environment standards: The benefit - cost or non-cost paradigm. J. Econ. Perspect. (1986 - 1998) 9:132.

Peduzzi P, Chatenoux B, Dao H, De Bono A, Herold C, Kossin J, Mouton F, Nordbeck O(2011). Global Trends in Tropical cyclone Risk, Nature, Climate, Change 2011.

Porter ME, Krammer MR (2006). Strategy and society: The link between competitive advantage and corporate social responsibility. Havard Business Review 84:78-92.
Reinhardt F (1999). Bringing the Environment down to Earth Havard Business Review July- August 1999: 149-157

Riddell R (1981).Eco development: Economics, Ecology, and Development: An Alternative to Growth Imperative Models. Gower London.

Sessions G, Devall B(1985). Deep Ecology: Living as if nature mattered, Peregine Smith Books Salt Lake City U.T

Speth JG (1989). A Luddite recants Amicus. 11(2):3-5.

Turral H, Burke I, Faures J(2011). Climate Change and Food Security, Water Report 36, Rome: FAO.

United Kingdom Met. Office (2010), Evidence, the State of the Climate, http://www.metoffice.gov.uk/media/pdf/m/6/evidence.pdf.

United Nations(2011), The Millennium Development Goals Report 2011, United Nations New York. http://www.un.org/millenniumgoals/11MDG\%20Report-EN.pdf.

Vitousek, PM, Ehrlich PR, Ehrlich AH, Matson PA (1986). Human Appropriation of the products of photosynthesis. BioScience 34: 386 373. 